\title{
Geological Composition and Structure of the Filling Zone and Its Water-Resisting Property Evaluation on the Top of Ordovician Limestone
}

\author{
Qiqing Wang, ${ }^{1}$ Wenping $\mathrm{Li}\left(\mathbb{D},{ }^{1}\right.$ and Qiangqiang $\mathrm{Liu}^{2}$ \\ ${ }^{1}$ School of Resources and Geosciences, China University of Mining and Technology, Xuzhou 221116, China \\ ${ }^{2}$ Inner Mongolia Power Survey \& Design Institute Co. Ltd., Hohhot 010011, China \\ Correspondence should be addressed to Wenping Li; wpligroup@163.com
}

Received 17 December 2018; Accepted 28 February 2019; Published 14 April 2019

Academic Editor: Mauro Cacace

Copyright (C) 2019 Qiqing Wang et al. This is an open access article distributed under the Creative Commons Attribution License, which permits unrestricted use, distribution, and reproduction in any medium, provided the original work is properly cited.

\begin{abstract}
With the gradual increase in mining depth of coal fields in North China, the threat posed by karstic Ordovician limestone water to the safe stoping of mines is becoming increasingly prominent. Investigating the water-resisting property of the filling zone on the top of the Ordovician limestone provides the key to safe mining under pressure. This paper analyzed the formation process of the filling zone on the top of Ordovician limestone in North China, and by combining analysis results of several geological field investigations on Ordovician outcrops, the filling zone on the top of Ordovician limestone was divided into three water-resisting structures: (1) completely filled, (2) incompletely filled, and (3) nonfilled. Based on the lithological composition, logging curves, and the water inflow status of several field boreholes, various characteristics of these clay-filled zones were used to determine the mudstone content from top to bottom. Using the interbedded mudstone thickness ratio, relative argillaceous content, impermeable filling zone thickness, rock quality designation (RQD), and faulting as evaluation factors, this paper evaluated the water-resisting property of the filling zone in the study area based on feature-weighted fuzzy C-means clustering (WFCM) algorithm and determined the extent of each zone. The completely filled zone accounts for $46.9 \%$ of the total area, incompletely filled zone accounts for $23.9 \%$, and the zone not filled with clay material accounts for $29.2 \%$. As indicated by field investigations on the boreholes, the actual percent of each zone is similar to the theoretical results. The study results present a vital guide for Ordovician limestone water control in deep mining.
\end{abstract}

\section{Introduction}

The Permo-Carboniferous system is the primary coalbearing formation in China [1-3], and the coal seams existing in its lower section are widely threatened by underlying karstic Ordovician limestone water. Karstic Ordovician limestone water constitutes a strong regional aquifer in North China, while also being a potential hazard in the form of floor water invasion and water damage accidents in coal mines [4-6]. For instance, on January 16, 1992, in mining area No. 2 of the Yangzhuang Coal Mine, Ordovician limestone water rushed into the mine through a fault, with a maximum water inflow of $5,890 \mathrm{~m}^{3} / \mathrm{h}$, and flooded the entire mine. On March 1, 2010, in the development of coal roadway
No. 16 in the Camel Hill Mine, the floor was flooded by the Ordovician limestone aquifer with a maximum water inrush of $60,036 \mathrm{~m}^{3} / \mathrm{h}$, which killed 32 people, injured 7 , and caused a direct economic loss of 48.53 million RMB [7]. In currently producing coal mines in North China, the coal reserves threatened by floor karstic water account for about $18.6 \%$ of the total reserves; in some old mining areas, the proportion can exceed $50 \%$. With the increase of mining depth, the threat posed by floor Ordovician limestone water flooding the mine is becoming even more prominent.

For years, scholars have classified the carbonate rock as an aquifer [8-15]; however, according to studies on the typical water yield of Ordovician limestone in North China, due to the filling of paleokarst weathering fissures 


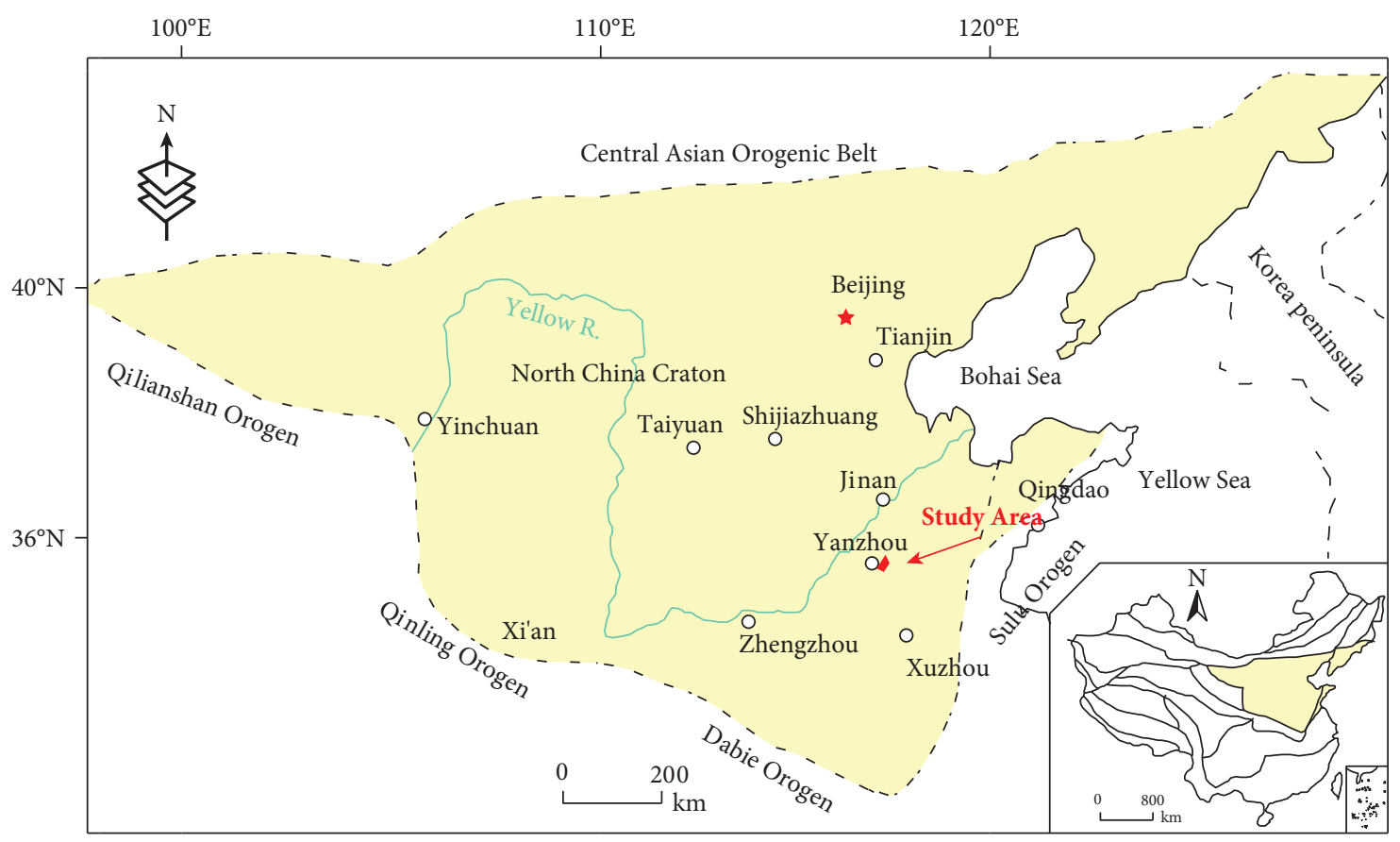

FIgURE 1: Location map of the study area (modified from [26]).

by argillaceous (calcareous) substances to varying degrees on the top section of the Ordovician karsts, the top of the Ordovician limestone manifests a universal weak water yield [16-18] and is referred to as the "filling zone." In some sections, the filling zone can be classified as an aquiclude, increasing the distance between the coal seams and the top interface of the Ordovician limestone, reducing the coefficient of water inrush below the critical coefficient of water inrush, and allowing for safe mining of coal seams. Currently, studies on the filling zone on the top of Ordovician limestone mainly focus on the development of karsts [17, 19], covering the micromechanisms of karsts $[20,21]$, genetic mechanisms of karst caves and collapse columns [22, 23], water yield properties of karsts [24, 25], etc. However, they rarely deeply examine the differences among the filling zones in terms of structural characteristics, water-resisting property, etc. Although the viewpoint that there is a filling zone on the top of the Ordovician limestone in North China is objective, it has been verified by mining under pressure practices in numerous mines; such a water-resistant section is not completely equivalent to general mudstone or a shale aquiclude, as its different zones have different water-resisting properties and do not constitute a homogenous unit.

This paper uses a typical mine in the coal fields of North China as an example and analyzes the structural characteristics of the argillaceous intercalation section on the top of Ordovician limestone based on Ordovician geological boreholes and logging data. The waterresisting properties of the limestone are then evaluated, and the limestone divided into three zones along with its aptitude as an aquiclude evaluated. The distribution of this impermeable layer is important for safe mining in the region.

\section{Study Area}

Xinglongzhuang Coal Mine is located in southeast Yanzhou, Shandong Province, about $8 \mathrm{~km}$ away from Yanzhou, and in the southeast portion of the North China Block of the North China Craton (Figure 1). The mine field is bounded by the Ziyang Fault to the north, the Dongtan Coal Mine to the southeast, and the Yangcun Coal Mine to the west. Its plane scope presents an irregular shape, with a strike length of about $13.1 \mathrm{~km}$, a slope width of about $6.8 \mathrm{~km}$, and an area of about $42.4 \mathrm{~km}^{2}$. Its main coal-bearing strata are the Permo-Carboniferous Shanxi and Taiyuan formations, which have stable coal measures and coal seam deposits and are classified as North China-type coal-bearing formations. The strata in the mine field indicated by boreholes include (from top to bottom) Quaternary (Q), Jurassic (J), Permian (P), Carboniferous (C), and Ordovician (O). The upper Ordovician was not deposited throughout this area, and the strata only consist of the middle and lower Ordovician $\left(\mathrm{O}_{1+2}\right)$. The middle Ordovician strata have a thickness of about $450 \sim 470 \mathrm{~m}$ and a burial depth of about $380 \sim 840 \mathrm{~m}$. It consists of greyish white-grey limestone and relatively developed karst caves. Its water is fissured karst cave confined water, which has an original water level elevation of $+38.29 \sim+39.47 \mathrm{~m}$ and provides the main water source for the mining of coal seam No. 16 and No. 17 in the region.

\section{Geological Composition and Structure of the Filling Zone}

3.1. Paleogeographic Characteristics. After the middle Cambrian, the North China Block was influenced by the Huaiyuan Movement [27], and its tectonic movement experienced seabed uplift, exposed denudation, oscillatory 


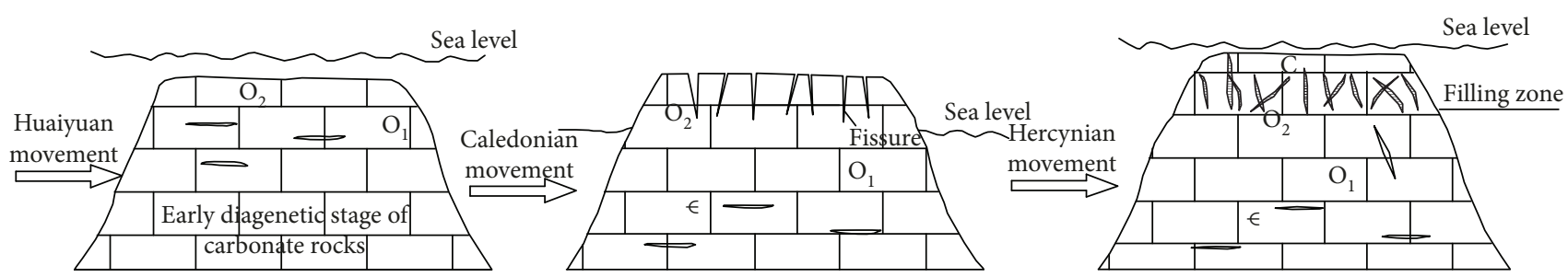

FIGURE 2: The developing stages of paleokarst in the North China Craton (modified from [28, 29]).

deposition, and other processes. In this stage, seawater underwent intense turbulences, and the sea transgression was exceedingly wide-ranging and lasted until the middle Ordovician (Ordovician limestone deposits at about $470 \mathrm{Ma})$. During the middle Ordovician, because of intermittent small-scale depositions and freshwater mixing and reformation due to marine ingressions and regressions, depositional karsts or interlayer karsts developed throughout the region (Figure 2(a)). After the middle Ordovician, influenced by the Caledonian Movement, the North China Block was entirely uplifted and experienced weathering denudation lasting almost 150 million years until the deposition of the middle Carboniferous Benxi Formation. This limestone was aerially exposed during this time of uplift and subjected to weathering denudation and dissolution, resulting in the formation of paleodenudation surface that was accompanied by the formation of paleokarst and numerous high-angle vertical dissolution fissures (Figure 2(b)). After the middle Carboniferous, the North China Platform began to subside and deposition of the Benxi Formation occurred, along with filling of the low-lying potholes and solution cracks by argillaceous materials forming the filling zone (Figure 2(c)). With further subsidence of the North China Block, seawater further invaded, and the fine-grained detrital bauxitic clay began to deposit on a relatively uplifted or detritus-filled site on the paleodenudation surface. Within the uplifted paleodissolution fissures in Ordovician limestone, or the coarse detritus deposited in the early period, karst fissures were once again filled by aluminous argillaceous material, further expanding the filling zone.

3.2. Structure Type of Filling Zone. The water resistance of the Ordovician limestone filling zone is mainly related to the development of karst fissures and the filling of these fissures. According to field geological investigations on the Ordovician outcrop sections in Yanzhou, Huaibei, and other adjacent regions, the degrees of development and forms of contact of the fissure structure planes and the degrees of filling by argillaceous minerals determined three zones:

(1) Completely Filled Structure. The karst fissures are completely or almost filled by argillaceous material, and the top of Ordovician limestone rock mass is characterized by severe weathering and intense fragmentation; locally, it appears more of an earthy status or a cohesive soil intercalated with detritus, rather than solid rock, so it is difficult to tell the status of original rock simply from appearance due to thorough physical changes (Figure 3(a)). Rock cores show that this interval consists of alternating limestone and fragmented mudstone and argillaceous fillers. The content of fine-grained silty and argillaceous sediment is far greater than coarse-grained detritus, and the fissures among rock blocks are completely filled and wrapped by clay-mineral fillers; there is no connection among rock blocks. The filling zone of such structural type has a very strong water-resisting capacity; classified as a waterresisting filling, it can be regarded as an aquiclude in engineering applications.

(2) Incompletely Filled Structure. The karst fissures are partially filled by argillaceous substances, and locally, the rock mass on the top of the Ordovician limestone is characterized by a lesser degree of weathering, relatively intact rock mass, clear original rock structure, and relatively stable structure. Several sets of fissures are well developed, and some are filled by argillaceous material, although the fissures are not completely filled (hence the term "incompletely filled" structure). There are connections among rock blocks, embodied in the characteristic of gravel-mud mixing (Figure 3(b)). The filling zone of such structural type has a relatively weak water resistance; however, compared with the lower Ordovician limestone stratum, its water-resistance capacity is still relatively strong; classified as a weakly water-resisting filling zone, it can absolutely be regarded as an aquiclude after grouting transformation.

(3) Nonfilled Structure. The karst fissures are not filled, or only slightly filled by thin films, and the rubble-rubble contact plays a dominant role among weathered rock blocks in the limestone. The fissures are interconnected and have a good water storage space. There is intense underground water dissolution, and on the macroscale, its nature is fragmented rock mass, which no longer has any essential difference from the underlying Ordovician limestone. This nonfilled structure can be classified as an aquifer, as it readily produces water (Figure 3(c)). This strong Ordovician limestone aquifer, characterized by deep burial depth, high water pressure, hard pumping, and difficult grouting transformation, is the key strata for floor water control for the safe mining of coal seams.

Because of the relatively weak lithology of the argillaceous fillers in the filled zone and because it would be constantly flushed with fluid during the drilling and coring process, coring of the filled zone is usually very difficult. As 


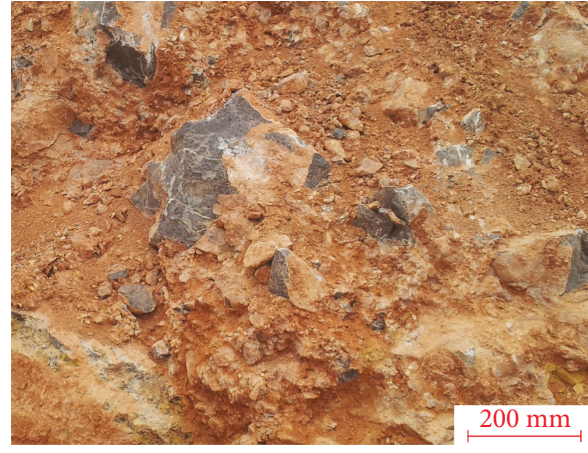

(a) Completely filled structure

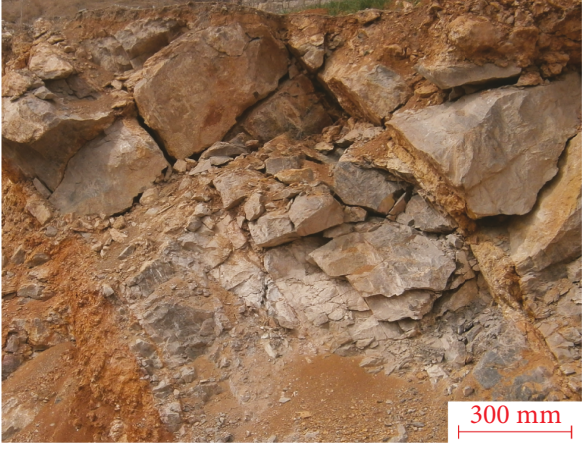

(b) Incompletely filled structure

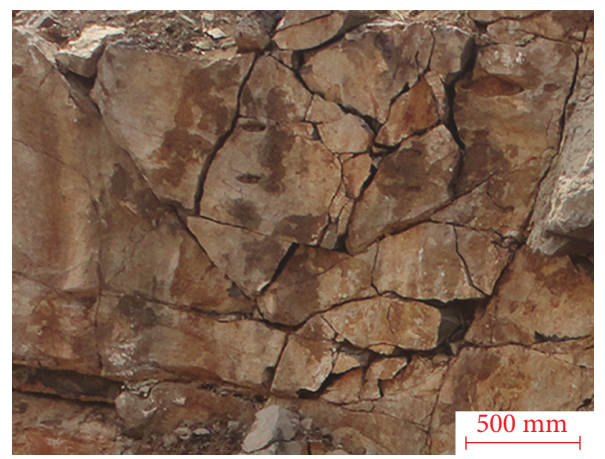

(c) Nonfilled structure

Figure 3: The field photo of a filled structure.

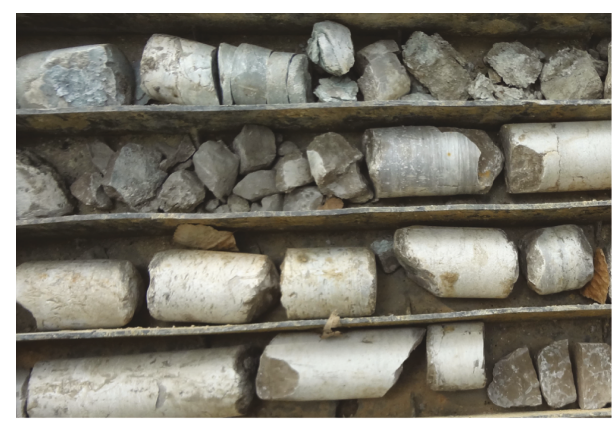

(a) Extremely fragmented rock core on the top of Ordovician limestone

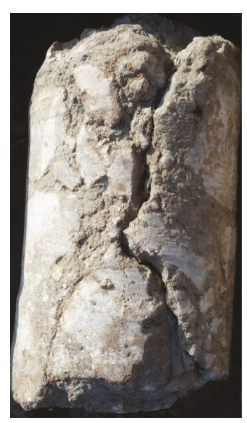

(b) The karst breccia on the top of

Ordovician limestone

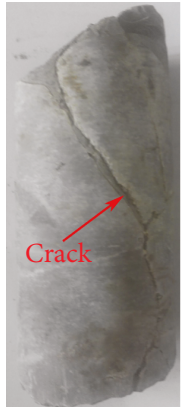

(c) The solution cracks filled by bauxitic fill

FIgURE 4: Drilling core on the top of Ordovician limestone.

shown by coring in the study area, within a certain scope on the top of Ordovician limestone, rock core is extremely fragmented, RQD is relatively low, and core intersection shows traces of weathering dissolution (Figure 4(a)). There are argillaceous fillers in the rock core fissures, and some fissures are closed. Although erosion by the drilling fluid has resulted in missing most of the argillaceous intercalation, in structure, it is consistent with the solution cracks and karst caves of the argillaceous intercalation observed in the Ordovician outcrops. As can be seen from Figure 4(b), essentially, the rock mass in this filling zone is completely weathered, and the structure of original rock has completely disappeared. It contains large amounts of pyrite and karst breccia, and dissolution fissures are mostly high-angle fissures. The solution cracks are mostly filled by bauxitic fill (Figure 4(c)). Through X-ray diffraction (XRD) analysis, the composition of aluminous clay is kaolinite and illite, but their contents vary greatly. Some of them contain $80 \%$ kaolinite and some 95\% illite [30].

3.3. Lithological Characteristics of the Filling Zone. According to field ground and subsurface borehole data of the study area, of the 41 boreholes consisting of the Ordovician limestone, 35 also contain mudstone and/or argillaceous limestone (mudstone observation rate in boreholes exceeding $85 \%$ ), and the observation depths range from $0.24 \mathrm{~m}$ to 


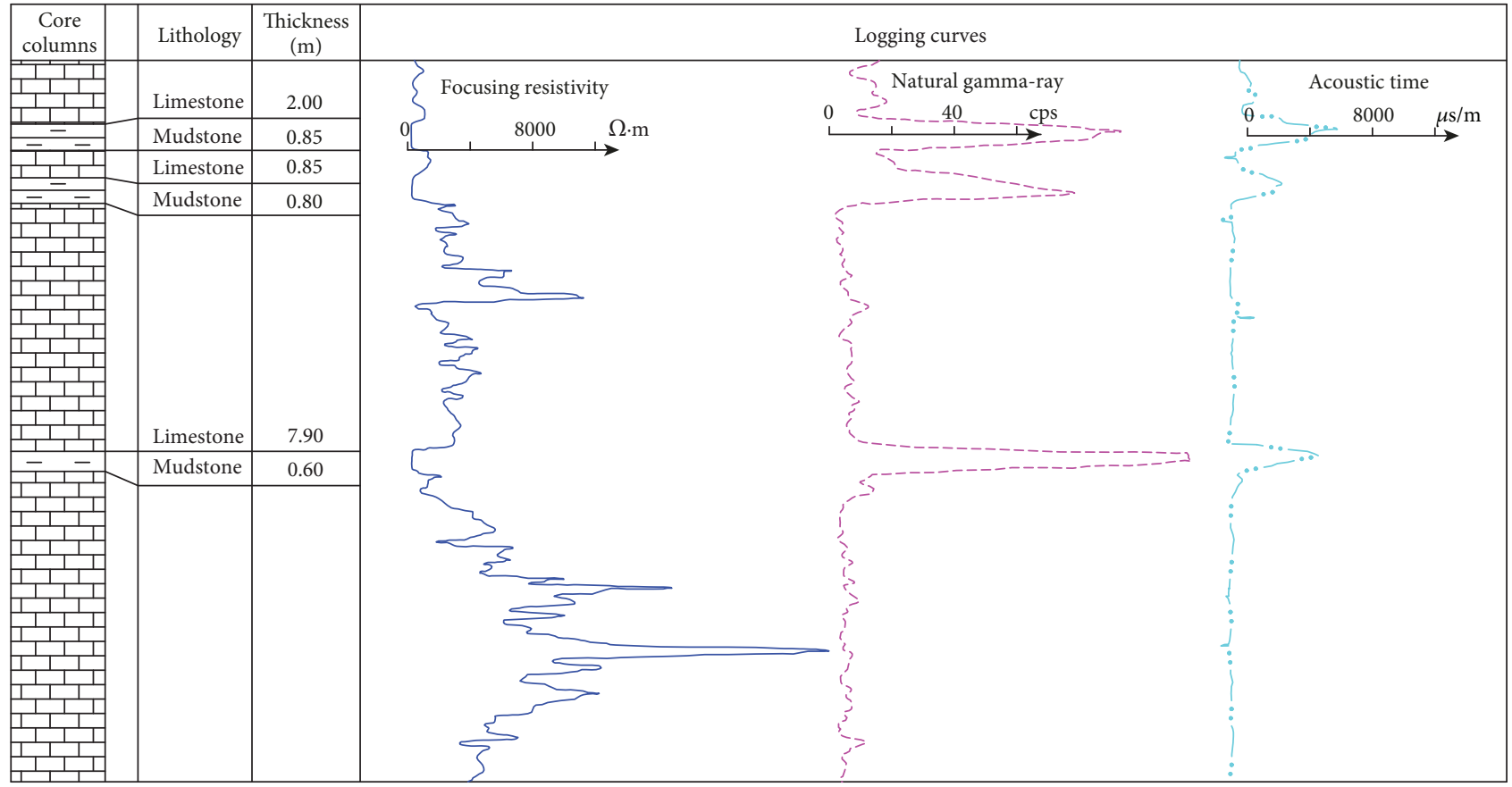

Figure 5: Column of O2-6 hole on the top of Ordovician limestone in the study area.

$52.98 \mathrm{~m}$ (largely within $1.0 \sim 20.0 \mathrm{~m}$ ). The range of mudstone thickness is $0.25 \sim 3.81 \mathrm{~m}$. According to observation of the rock core of boreholes, the upper section of the Ordovician limestone is greyish-white to grey limestone, massive, compact, pure, and brittle, with relatively developed fissures (2 3 $\mathrm{mm}$ in width). Filled by calcite crystals, the limestone is locally developed with small dissolution pores $(0.5 \sim 25 \mathrm{~mm}$ in diameter) and contains pyrite crystals. On the top, it is interbedded with 1 3 layers of argillaceous limestone and mudstone. Figure 5 depicts the column of ground exploration borehole O2-6 in the study area. The sites of $2 \mathrm{~m}, 3.7 \mathrm{~m}$, and $12.4 \mathrm{~m}$ after entering Ordovician limestone are interbedded with thin light-green mudstone. Seen from the logging curve, the argillaceous interbedded zone that is water-resistant on the top of Ordovician limestone is variable and grades from pure limestone at the bottom to argillaceous at the top. The top argillaceous interbedded zone appears to have resistivity, high natural gamma ray, and high interval transit time according to the logging data. The bottom limestone section with homogenous lithology has curve characteristics of high resistivity and stable, low natural gamma-ray, and interval transit time values.

3.4. Water Inflow Characteristics of the Filling Zone. The water inflow status of a borehole when drilling strata can intuitively reflect hydraulic characteristics of strata, including the water yield status, and the water-bearing and water-resisting information. It is an important approach to understand the hydraulic characteristics of underground aquicludes [31]. According to the statistics of 15 underground water discharge boreholes in the study area, there was no rush-out of Ordovician limestone water in any borehole before drilling the Ordovician limestone, and rush-out of Ordovician limestone water occurred only after entering into a certain depth of Ordovician limestone; that is, there was no guide rise zone for Ordovician limestone confined water. In addition, as can be seen from Table 1, of the 15 underground water discharge boreholes, 12 showed rush-out of Ordovician limestone water only after drilling to a certain depth of Ordovician limestone, suggesting that there is a prevalence of impermeable filling zones of various thicknesses on the top of Ordovician limestone in the study area. The area where there was no rush-out section in the limestone had a thickness between $2.54 \mathrm{~m} \sim 19.34 \mathrm{~m}$ and an average thickness of $9.5 \mathrm{~m}$, suggesting that the filling zone has different water resistance both vertically and spatially. Using FO2-S2 borehole as an example, from the top interface of the Ordovician limestone downward, drilling showed that the water inflow increased from $0.001 \mathrm{~m}^{3} / \mathrm{h}$ entering Ordovician limestone at a depth of $1.44 \mathrm{~m}$ to $150 \mathrm{~m}^{3} / \mathrm{h}$ at a depth of $170.01 \mathrm{~m}$, showing a decrease in water resistance with depth. Furthermore, the top karst fissure of this borehole was interbedded with mudstone. Also, there was rush-out in all three underground water discharge boreholes, and there was no incomplete interbedding of mudstone or karst fissures on the top in any borehole, which verifies the mechanism of water resistance by the clay-filled zone on the top of Ordovician limestone.

\section{Evaluation Factors of Water-Resisting Property for the Filling Zone}

The degree of development and spatial distribution of the filled zone on the top of the Ordovician limestone are 
TABLE 1: The water exit conditions of underground drain well.

\begin{tabular}{|c|c|c|c|c|}
\hline Borehole & $\begin{array}{c}\text { Thickness of Ordovician } \\
\text { limestone in exploration }(\mathrm{m})\end{array}$ & $\begin{array}{c}\text { Drilling footage in Ordovician } \\
\text { limestone }(\mathrm{m})\end{array}$ & Water inflow $\left(\mathrm{m}^{3} / \mathrm{h}\right)$ & $\begin{array}{c}\text { Thickness of no } \\
\text { water out section }(\mathrm{m})\end{array}$ \\
\hline \multirow{2}{*}{ FO2-1a } & \multirow{2}{*}{53.27} & 11.42 & Yielding water & 11.42 \\
\hline & & 53.27 & 8.16 & \\
\hline \multirow{2}{*}{ FO2-1b } & \multirow{2}{*}{52.93} & 8.92 & Yielding water & 8.92 \\
\hline & & 52.93 & 60.24 & \\
\hline \multirow{2}{*}{$\mathrm{FO} 2-2 \mathrm{a}$} & \multirow{2}{*}{72.06} & 11.96 & Yielding water & 11.96 \\
\hline & & 72.06 & 64.38 & \\
\hline \multirow{2}{*}{$\mathrm{FO} 2-2 \mathrm{c}$} & \multirow{2}{*}{66.71} & 10.79 & Yielding water & 10.79 \\
\hline & & 66.41 & 126.31 & \\
\hline \multirow{2}{*}{$\mathrm{FO} 2-3 \mathrm{a}$} & \multirow{2}{*}{99.01} & 5.70 & Yielding water & 5.7 \\
\hline & & 74.9 & 47.08 & \\
\hline \multirow{2}{*}{$\mathrm{FO} 2-3 \mathrm{~b}$} & \multirow{2}{*}{100.29} & 12.99 & Yielding water & 12.99 \\
\hline & & 100.29 & 48.51 & \\
\hline \multirow{2}{*}{$\mathrm{FO} 2-4 \mathrm{a}$} & \multirow{2}{*}{52.68} & 19.34 & Yielding water & 19.34 \\
\hline & & 20.83 & 65.83 & \\
\hline \multirow{2}{*}{$\mathrm{FO} 2-4 \mathrm{~b}$} & \multirow{2}{*}{77.14} & 16.50 & Yielding water & 16.50 \\
\hline & & 77.14 & 36.86 & \\
\hline \multirow{2}{*}{ FO2-5 } & \multirow{2}{*}{50.88} & 7.06 & Yielding water & 7.06 \\
\hline & & 50.88 & 23.36 & \\
\hline \multirow{5}{*}{ FO2-6 } & \multirow{5}{*}{50.64} & 3.38 & Yielding water & 3.38 \\
\hline & & 9.45 & 8.24 & \\
\hline & & 25.57 & 110.67 & \\
\hline & & 32.18 & 119.4 & \\
\hline & & 50.64 & 135 & \\
\hline \multirow{5}{*}{$\mathrm{FO} 2-7$} & \multirow{5}{*}{55.82} & 3.45 & 1 & 3.45 \\
\hline & & 9.01 & 5.6 & \\
\hline & & 25.43 & 7.06 & \\
\hline & & 43.8 & 21 & \\
\hline & & 55.82 & 175 & \\
\hline \multirow{2}{*}{ FO2-10 } & \multirow{2}{*}{99.98} & 9.96 & 0.2 & 9.96 \\
\hline & & 99.98 & 23.4 & \\
\hline & & 64.58 & 13 & 0 \\
\hline FO2-12 & 99.86 & 72.79 & 38.64 & \\
\hline & & 99.86 & 75.06 & \\
\hline FO2-14 & 2.58 & 2.58 & 15.65 & 0 \\
\hline FO2-16 & 99.76 & 43.29 & 1.9 & 43.29 \\
\hline FUL-16 & 99.16 & 99.76 & 81 & \\
\hline FO2-18 & 99.16 & 38.54 & 27 & 0 \\
\hline$\Gamma \cup \angle-10$ & 99.10 & 99.16 & 82.18 & \\
\hline & & 1.44 & 0.01 & 1.44 \\
\hline & & 2.54 & 0.03 & \\
\hline & & 8.20 & 4.43 & \\
\hline $\mathrm{FUL-S} 2$ & 21.04 & 19.20 & 8.86 & \\
\hline & & 60.84 & 61.3 & \\
\hline & & 170.01 & 150 & \\
\hline
\end{tabular}


controlled by carbonate rock lithology and structure, tectonic faulting, paleotopography, paleogeomorphy, paleoclimate, and many other factors. The differences in the degree of development of karst, amount of clay fill material, late reformation of geological structures, and compaction of overlying strata have given rise to anisotropy in the water resistance of the clay-filled zone on the top of Ordovician limestone. Based on numerous Ordovician exploration boreholes, hydrogeological tests, logging data, and so forth in the study area, this paper analyzed the formation process, filled structures, hydrogeological characteristics, variations in and other aspects of the filling zone on the top of Ordovician limestone, and selected lithological characteristic indexes, karst fissure characteristic indexes, and structural characteristic index as indexes for evaluating the water resistance of the filling zone on the top of Ordovician limestone; the evaluation factors include interbedded mudstone thickness ratio, relative argillaceous content, impermeable filling zone thickness, rock quality designation (RQD), and faulting.

\subsection{Lithological Characteristic Indexes}

4.1.1. Interbedded Mudstone Thickness Ratio. The interbedded mudstone thickness is related to the filling space and filling degree of paleokarst fissures and karst caves and is an important index reflecting the water resistance of the filling zone on the top section of the Ordovician limestone. The weathered material that filled in solution cracks and karst caves has obstructed further development of paleokarst, and, through compaction by the overlying strata, an impermeable filling zone has formed. These strata have also subducted and obstructed, creating highly confined karst water. The permeability of mudstone is significantly lower than that of limestone, so it serves as an ideal water-resistant stratum; a higher thickness of interbedded mudstone indirectly reflects a stronger water resistance on the part of the filling zone on the top of Ordovician limestone. This paper introduces a ratio of mudstone thickness to impermeable filling zone thickness as an evaluation factor; see the distribution of interbedded mudstone thickness ratio in Figure 6(a).

4.1.2. Natural Gamma-Ray Logging. Due to mud flushing during the drilling process, it is very difficult to acquire samples of the thin mudstone in rock core from a borehole, and it is impossible to obtain an accurate clay content from the column of the borehole. Natural gamma-ray logging (GR) is a geophysical method that measures the intensity of gamma rays released by the radioactive nuclear decay of various elements existing naturally in strata in mines; usually, it is used to classify lithology, estimate the clay content of a stratum, and perform stratigraphic correlations. The natural gamma-ray (GR) curve can be used to estimate argillaceous content by the following formula:

$$
V_{\mathrm{sh}}=\frac{2^{\mathrm{GCUR} \times I}-1}{2^{\mathrm{GCUR}}-1},
$$

wherein, $V_{\text {sh }}$ represents the argillaceous content at a given depth; GCUR represents the Hilchie index, generally set as 2 for old strata and as 3.7 for young strata; and $I_{\mathrm{GR}}$ represents the natural gamma-ray relative value of the target stratum at a particular depth, which can be calculated by the following formula:

$$
I_{\mathrm{GR}}=\frac{\mathrm{GR}-\mathrm{GR}_{\min }}{\mathrm{GR}_{\max }-\mathrm{GR}_{\min }},
$$

wherein, GR represents the natural gamma-ray value of the target stratum; $\mathrm{GR}_{\max }$ represents the natural gammaray index of pure mudstone (the highest GR value on the curve); and $\mathrm{GR}_{\min }$ represents the natural gamma-ray index of pure limestone (the lowest GR value on the curve). The above formula can be used to calculate the argillaceous content of the filling zone on the top of Ordovician limestone in the study area; see the distribution of relative argillaceous content in Figure 6(b).

\subsection{Karst Fissure Characteristic Indexes}

4.2.1. Impermeable Filling Zone Thickness. The status of water inflow determined by underground boreholes can directly reflect the water-bearing and water-resisting properties of a stratum and is a comprehensive index of the influencing factors of karst development, fissure filling, and faulted structure. When the thickness of the formation that allows water inflow determined during the drilling process is less than the water-resisting property threshold $Q$ (about $1 \sim 2 \mathrm{~m}^{3} / \mathrm{h}$ ), it is adopted as karst fissure characteristic index, as a higher impermeable filling zone thickness means a stronger subduction on the part of the filling zone for underlying Ordovician limestone water and further indicates stronger water resistance. Otherwise, the filling zone is determined as having weaker water resistance (allows for more fluid flow). See the distribution of impermeable filling zone thickness in the study area in Figure 6(c).

4.2.2. Rock Quality Designation (RQD). Rock quality designation (RQD), which is defined as the percentage of the sum of the lengths of the core pieces longer than $10 \mathrm{~cm}$ to the total core run length [32], has been used as an index for the degree of rock mass fracture. When the RQD of the filling zone is low, it means a low rock mass quality, poor rock mass integrity, more developed fissured karst caves and weak intercalations, low compaction and filling degrees, and stronger permeability. It also indicates weak water resistance. See the distribution of RQD in the study area in Figure 6(d).

4.3. Structural Characteristic Index. Geologic structures can readily affect the water resistance of a formation. Faults can damage the integrity of the filling zone and cause discontinuity, and they also control the development direction and depth of karst formation. Since its formation in the Carboniferous period, the filling zone on the top of Ordovician limestone has experienced several late 


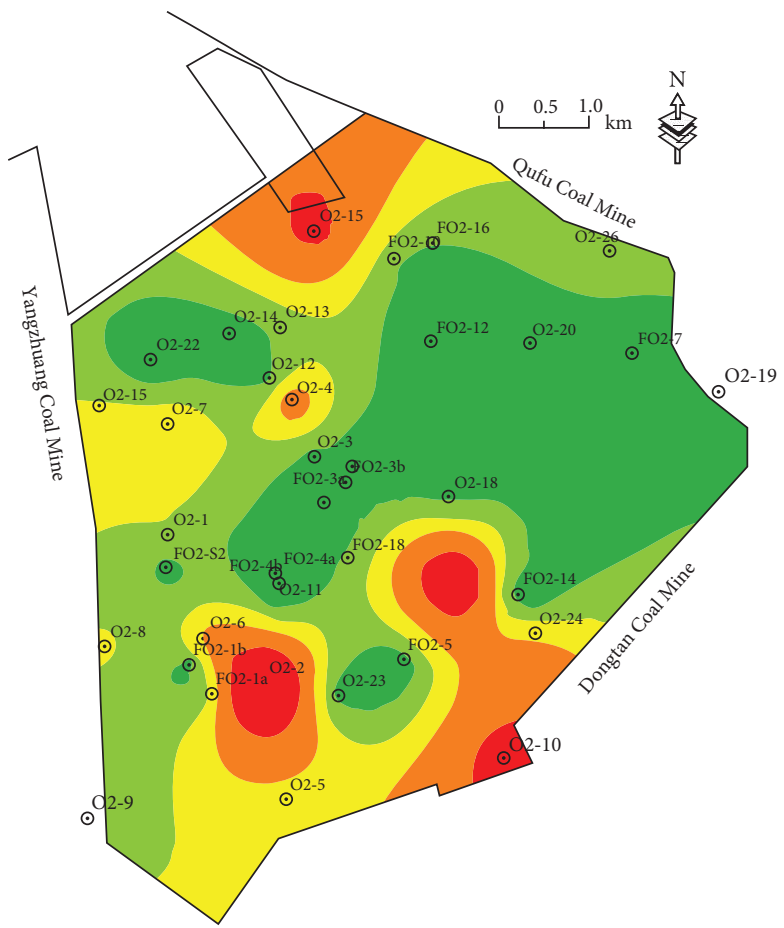

Interbedded mudstone thickness ratio

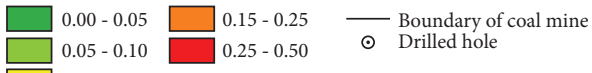

(a)

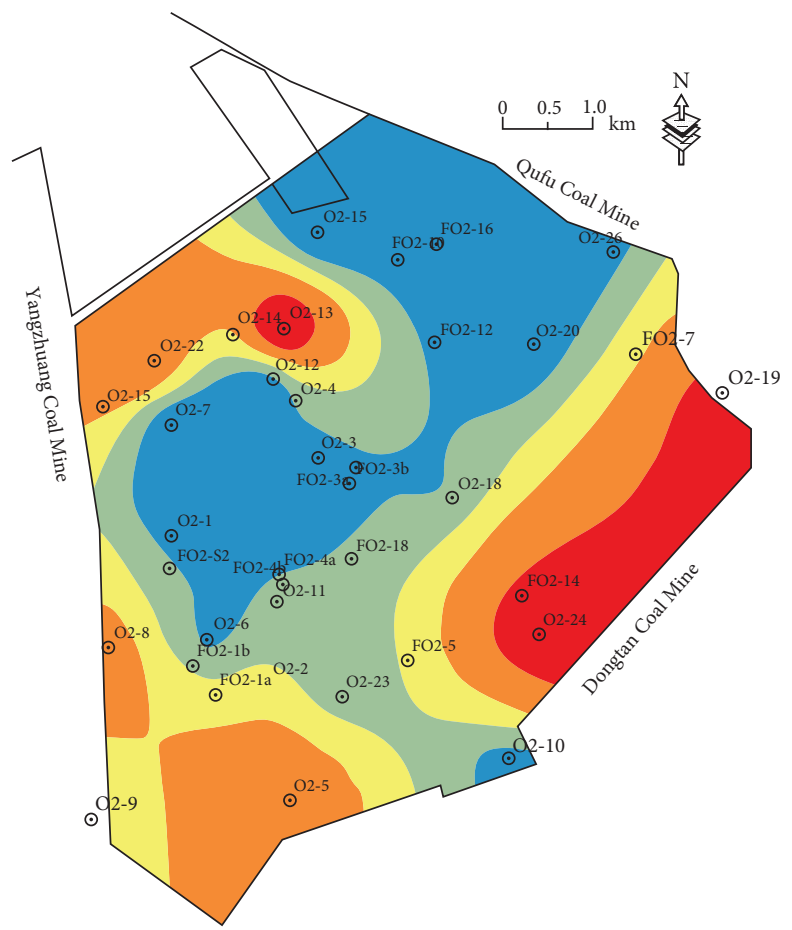

Relative and argillaceous content based on GR

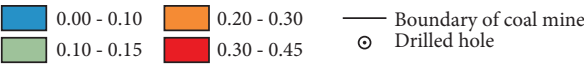

$0.10-0.15$

(b)

FIGURE 6: Continued. 


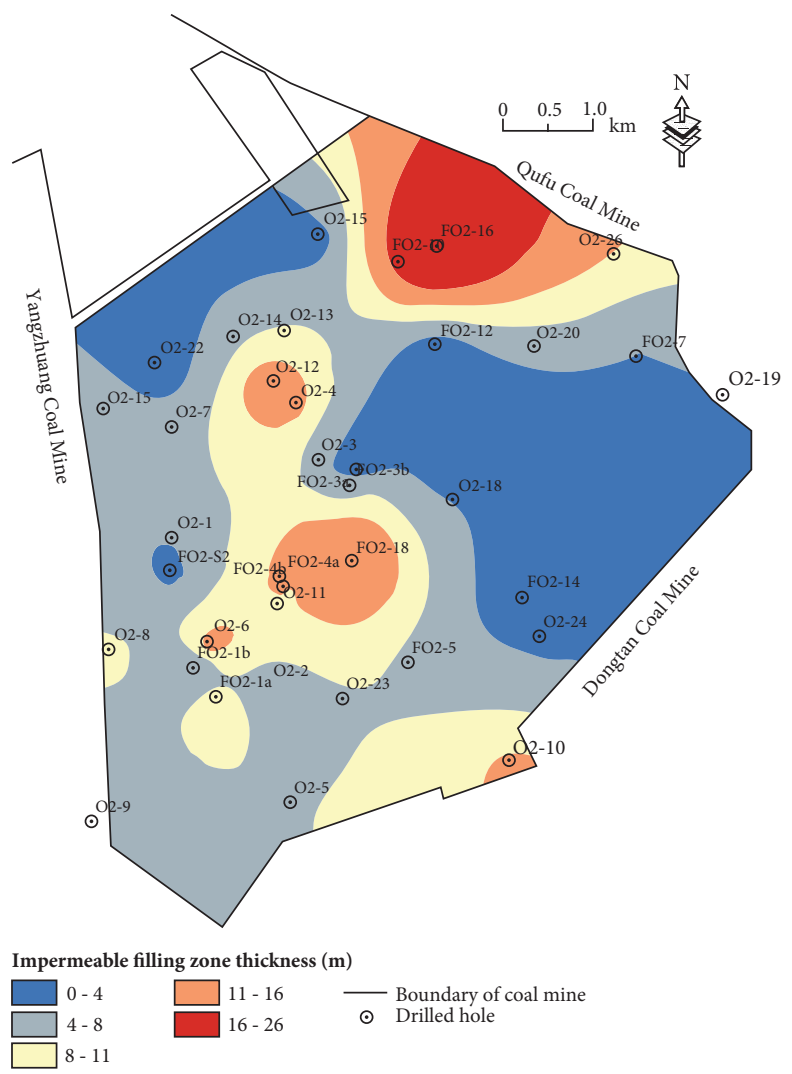

(c)

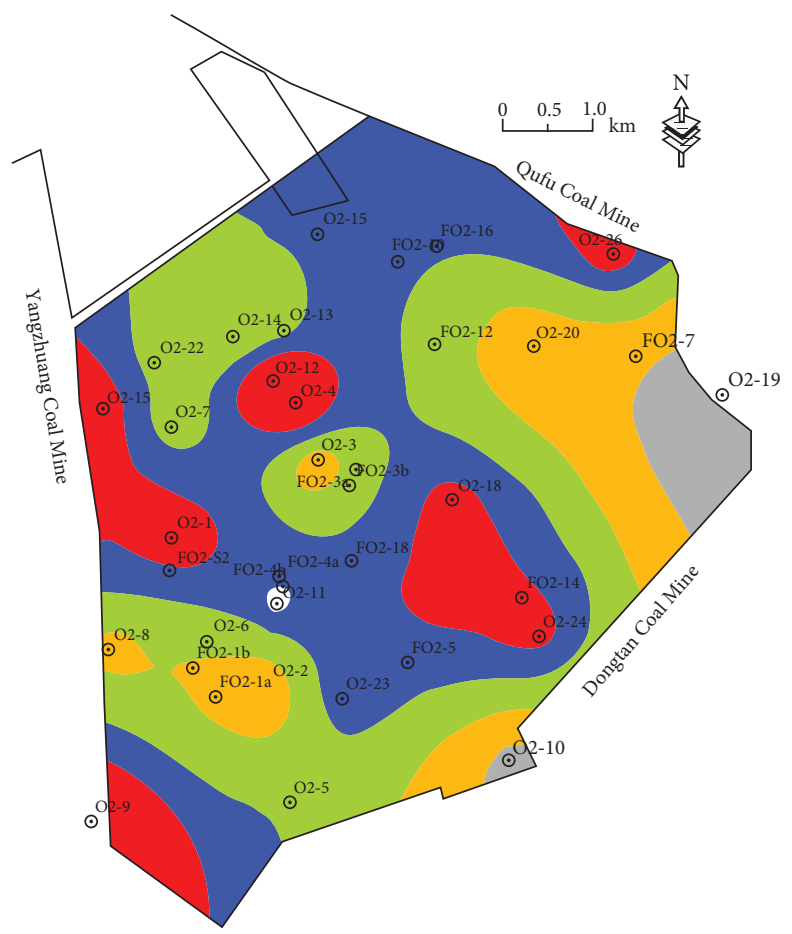

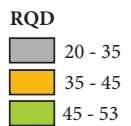

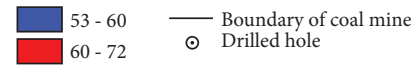

(d)

FIgure 6: Continued. 


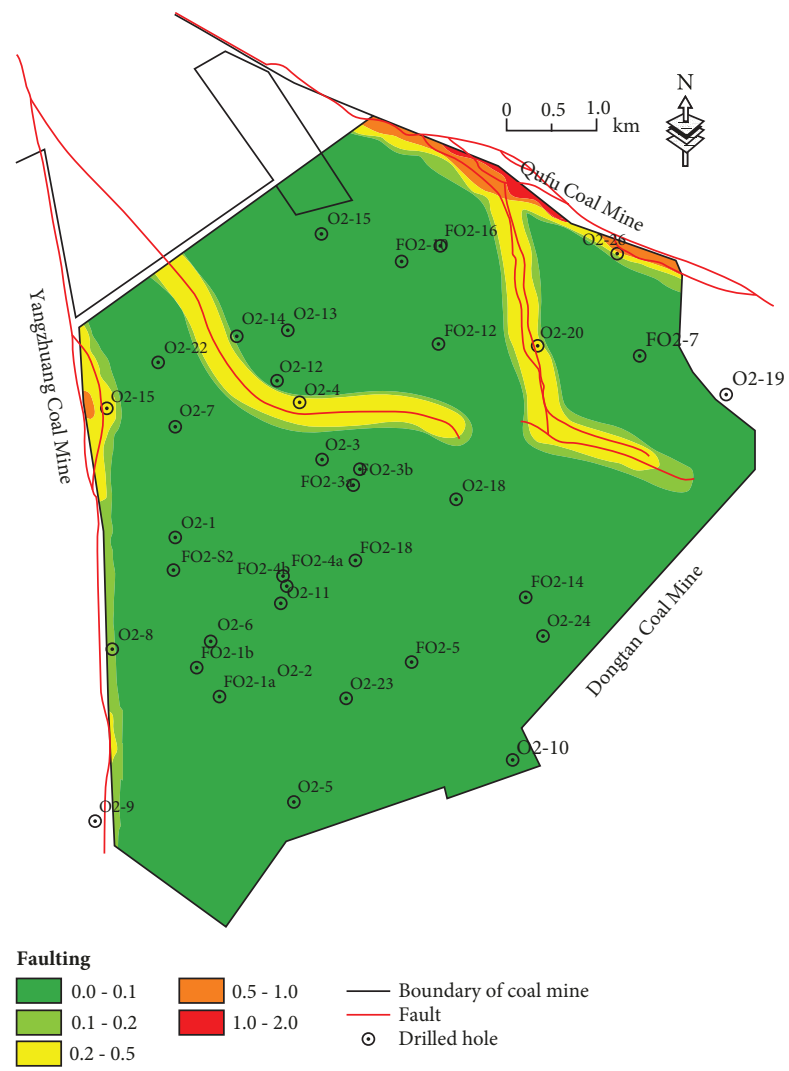

(e)

FIGURE 6: Maps of evaluation factors: (a) interbedded mudstone thickness ratio; (b) relative argillaceous content; (c) RQD; (d) impermeable filling zone thickness; (e) faulting.

geological movements, and faults have damaged the integrity and increased the permeability of rocks. According to previous studies [33], the scope of influence of faults on the water-resisting property of the filling zone is $200 \mathrm{~m}$. When faulting serves as a multivariate evaluation factor, it is necessary to do fault quantification. Fault quantification was realized in this paper through calculating the density of fault scale lines. Each data point was used as the center to draw a circle $200 \mathrm{~m}$ in radius. The product of the length was calculated for each fault falling within the corresponding circle and also the drop in level number. Finally, the cumulative sum of products was calculated, and the ratio of the cumulative sum to circle area was obtained. See the density distribution of fault scale lines in the study area in Figure 6(e).

\section{Evaluation Method of Water-Resisting Property for the Filling Zone}

This paper used an improved fuzzy $C$-means algorithm, that is, feature-weighted fuzzy $C$-means clustering (WFCM), to evaluate the water-resisting properties of the filling zone. Fuzzy $C$-means algorithm uses the Euclidean distance $d_{k i}=\left\|x_{k}-c_{i}\right\|$ between a sample data point and cluster center as the index measuring dissimilarity between the two and assumes that the multidimensional features of a cluster sample data point have equal importance for clustering; however, in actual situations, the contributions made by the multidimensional features of a data point to the clustering results are apparently different. With regard to this problem, the concept of feature weight was introduced in this paper into fuzzy $C$-means clustering to improve fuzzy $C$-means algorithm, thus obtaining feature-weighted fuzzy $C$-means clustering algorithm. The multidimensional features of the sample data points are weighted according to their degrees of importance, so as to strengthen the role of primary features in the clustering analysis, weaken the misleading effects of secondary features for clustering results, and improve the accuracy of clustering results.

5.1. Determination of Feature Weights. This paper adopted the entropy method to determine the weights of various indexes. Essentially, the greater the amount of information in a system, the lower the uncertainty, the smaller the entropy, and the higher the weight, and vice versa $[34,35]$. Assuming that $x_{i j}(i=1,2, \cdots, m ; j=1,2, \cdots, n)$ represents the observation data of the $j^{\text {th }}$ index of the $i^{\text {th }}$ data point, for a given index $j$, the greater the difference in $x_{i j}$, the greater the role played by this index in comprehensive evaluation. If the values of an index are all 
equal, then the index will not have any role in the comprehensive evaluation. The specific steps of determining the index weights according to the entropy method are as follows:

(a) Calculate the feature weight $p_{i j}$ occupied by the $i^{\text {th }}$ data point under the $j^{\text {th }}$ index:

$$
p_{i j}=\frac{x_{i j}}{\sum_{i=1}^{m} x_{i j}}
$$

(b) Calculate the entropy $e_{j}$ of the $j^{\text {th }}$ index:

$$
e_{j}=-k \sum_{i=1}^{m} p_{i j} \ln p_{i j}
$$

wherein, $k>0$ and $e_{j}>0$, if the values of the $j^{\text {th }}$ index are all equal, then $p_{i j}=1 / m$ and $e_{j}=k \ln m$

(c) Calculate the difference coefficient $g_{j}$ for various indexes:

$$
g_{j}=1-e_{j}
$$

that is, the greater the difference coefficient $g_{j}$, the greater the importance that should be attached to that index

(d) Provide normalization processing for $g_{j}$ to obtain the weight $w_{j}$ of each index:

$$
w_{j}=\frac{g_{j}}{\sum_{i=1}^{m} g_{j}}, \quad j=1,2, \ldots, n
$$

5.2. WFCM Algorithm. The basic idea of the WFCM algorithm is that, for a given sample set $X=\left\{x_{1}, x_{2}, x_{3}, \cdots, x_{n}\right\}$ containing $n d$-dimensional vector data, $x_{k}=$ $\left\{x_{k 1}, x_{k 2}, x_{k 3}, \cdots, x_{k d}\right\}^{\mathrm{T}} \in R^{d}$ corresponds to a point in the feature space, and $x_{k j}$ represents the assignment of the $j^{\text {th }}$-dimensional feature of data point $x_{k}$. By classifying $n$ sample data points $x_{k}(k=1, \cdots, n)$ into $c$ cluster classes $G_{i}(i=1, \cdots, c)$ and solving the cluster center $c_{i}$ of each cluster class, the target function representing the dissimilarity index between cluster classes is minimized; the dissimilarity index is the distance between each sample data point and cluster center.

Assuming that the given feature weight vector is $W=$ $\left[w_{1}, w_{2}, \cdots, w_{d}\right]^{\mathrm{T}}$, generally meeting

$$
\begin{aligned}
w_{t} & \geq 0, \quad t=\{1,2, \cdots, d\} \\
\sum_{t=1}^{d} w_{t} & =1,
\end{aligned}
$$

then, the featured-weighted Euclidean distance between the sample data point $x_{k j}$ and cluster center $c_{i}$ is

$$
d_{w-i j}=d\left\|x_{j}-c_{i}\right\|_{w}=\left[\left(x_{j}-c_{i}\right)^{\mathrm{T}} W^{2}\left(x_{j}-c_{i}\right)\right]^{1 / 2} .
$$

WFCM adopts the fuzzy method to divide cluster classes, uses degrees of association between 0 and 1 , and allows the association of a data point under various cluster classes (value ranging between 0 and 1), except that the sum of the degrees of association by which a data point is attributed to various cluster classes sums to 1 ; that is, the constraint condition is

$$
\sum_{i=1}^{c} u_{i j}=1, \quad \forall j=1, \ldots n
$$

The clustering criterion minimizes the target function, and the target function of WFCM is

$$
J_{\mathrm{WFCM}}=\sum_{i=1}^{c} \sum_{j=1}^{n} u_{i j}^{m}\left\|x_{j}-c_{i}\right\|_{w}^{2}=\sum_{i=1}^{c} \sum_{j=1}^{n} u_{i j}^{m} d_{w-i j}^{2},
$$

wherein, $u_{i j}$ represents the degree of association by which the $j^{\text {th }}$ data point is attributed to cluster class $G_{i}$ (value ranging between 0 and 1 ) and $m \in[1, \infty)$ is the fuzzy control parameter, set as $1.5 \leq m \leq 2.5$, and according to previous experience, it was generally set to 2 . The fuzzy $C$-means clustering problem can be converted into a mathematical problem for finding the optimal solution:

$$
\left\{\begin{array}{l}
\min J_{\mathrm{WFCM}}(U, P)=\sum_{i=1}^{c} \sum_{j=1}^{n} u_{i j}^{m} d_{w-i j}^{2}, \\
\sum_{i=1}^{c} u_{i j}=1, \quad 1 \leq j \leq n, \\
0<\sum_{j=1}^{n} u_{i j}<n, \quad 1 \leq i \leq c, \\
0 \leq u_{i j} \leq 1, \quad i=1, \ldots, c, j=1, \ldots, n .
\end{array}\right.
$$

Through solving the above formula according to the Lagrangian multiplier method, the Lagrange function can be constructed as follows:

$$
\begin{aligned}
J\left(U, P, \lambda_{1}, \cdots, \lambda_{n}\right) & =J_{\mathrm{WFCM}}(U, P)+\sum_{j=1}^{n} \lambda_{j}\left(\sum_{i=1}^{c} u_{i j}-1\right) \\
& =\sum_{i=1}^{c} \sum_{j=1}^{n} u_{i j}^{m} d_{w-i j}^{2}+\sum_{j=1}^{n} \lambda_{j}\left(\sum_{i=1}^{c} u_{i j}-1\right),
\end{aligned}
$$

wherein, $\lambda_{j}(j=1, \cdots, n)$ represents the Lagrangian multiplier of $n$ constrained formulas of formula (9); through solving the partial derivatives of the input parameters 


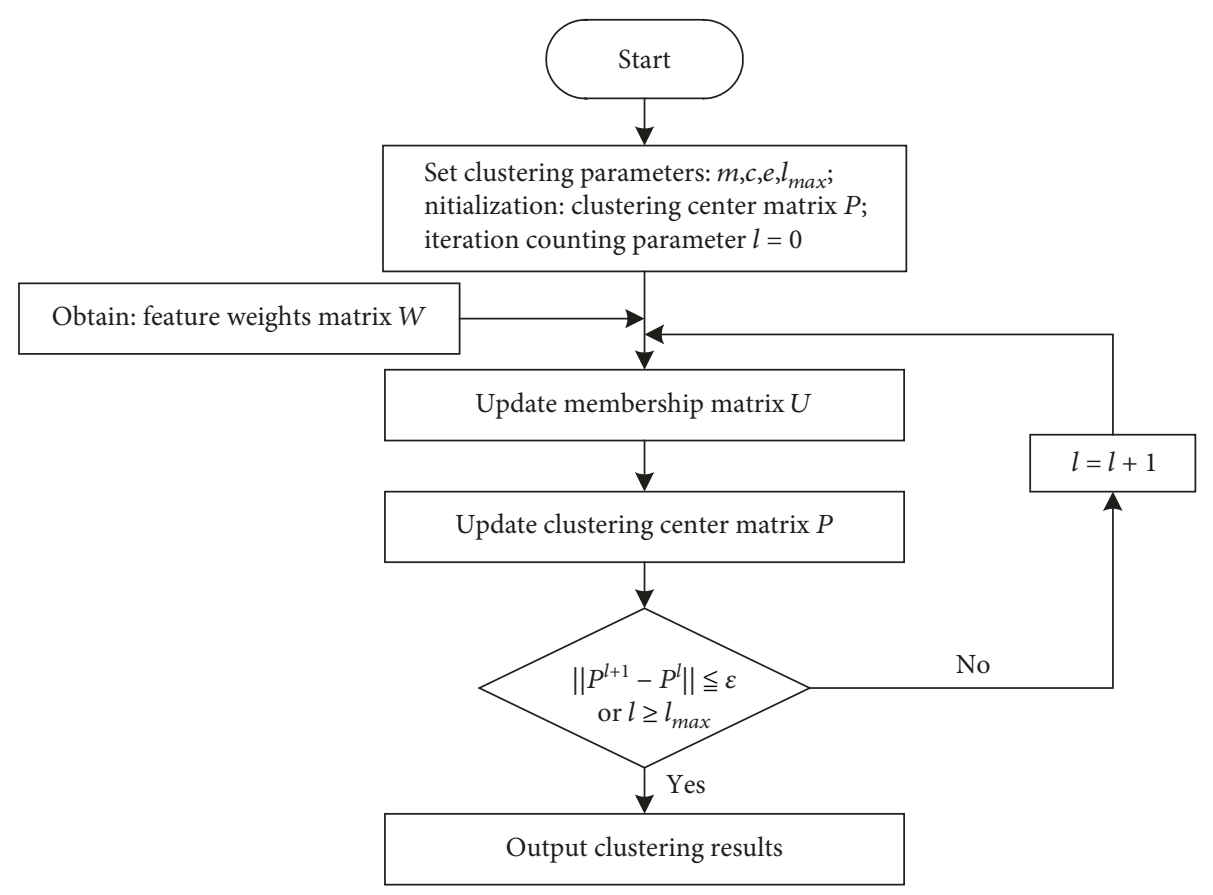

Figure 7: Flow chart of the WFCM algorithm.

TABLE 2: The weight of condition factors obtained from the entropy method.

\begin{tabular}{lcccc}
\hline Evaluation factors & $\begin{array}{c}\text { Interbedded mudstone } \\
\text { thickness ratio }\end{array}$ & $\begin{array}{c}\text { Relative argillaceous } \\
\text { content }\end{array}$ & $\begin{array}{c}\text { Impermeable filling } \\
\text { zone thickness }\end{array}$ & RQD \\
\hline Weights & 0.279 & 0.181 & 0.193 & 0.021 \\
\hline
\end{tabular}

and assuming the result as 0 , the necessary conditions that minimize the target function can be obtained in combination with the constrained formulas as follows:

$$
\begin{aligned}
& \left\{\begin{array}{l}
\frac{1}{\sum_{k=1}^{c}\left(d_{w-i j} / d_{w-k j}\right)^{2 /(m-1)}}, \quad d_{w-k j}>0(1 \leq j \leq c), \\
1, \quad d_{w-i j}=0(1 \leq i \leq c), \\
0, \quad \exists j, j \neq i, d_{w-k j}=0,
\end{array}\right. \\
& c_{w-i}=\frac{\sum_{j=1}^{n} u_{w-i j}^{m} x_{j}}{\sum_{j=1}^{n} u_{w-i j}^{m}} .
\end{aligned}
$$

The Euclidean distance in the WFCM algorithm has introduced a feature weight $W$, and $\mathrm{AO}$ alternating iterative method is adopted to estimate and solve parameter clustering center matrix $P$ and association matrix $U$. The specific steps are shown in Figure 7.

\section{Evaluation Result of Water-Resisting Property for the Filling Zone}

Through creating a multivariate comprehensive evaluation factor set for the water-resistance properties of the filling zone on the top of Ordovician limestone, this paper used MATLAB to calculate the ultimate entropy weight (Table 2).
Normalization function was used to provide normalizing nondimensionalization processing for these factors, and, in the process of calculating the Euclidean distance, it introduced the feature weight $W$, set clustering parameters, and conducted clustering analysis on the normalized factors. Based on the above analysis on the waterresisting structures of the filling zone, three clustering results established the grade evaluation results of waterresisting properties. See the final grade partition of the water-resisting properties of the filling zone of Ordovician limestone in Figure 8, and see the specific cluster centers and data points in Table 3.

The interbedded mudstone thickness ratio and impermeable filling zone thickness for the class 1 cluster were greater than those of the other two classes, and its fault line density was lower; as can be known from the above analysis, its water-resisting property was stronger than that of the other classes, so class 1 was regarded as the completely filled zone. The interbedded mudstone thickness ratio and impermeable filling zone thickness of the class 2 cluster were greater than those of the class 3 cluster, and its fault line density was lower than that of class 3 , so it was concluded that the water resistance of the filling zone was stronger than that of class 3 . The fault line density for the class 3 cluster was higher than that for the other two clusters, and its higher natural gamma-ray logging factor was caused by fragmented rock mass; the interbedded mudstone thickness ratio, impermeable filling 


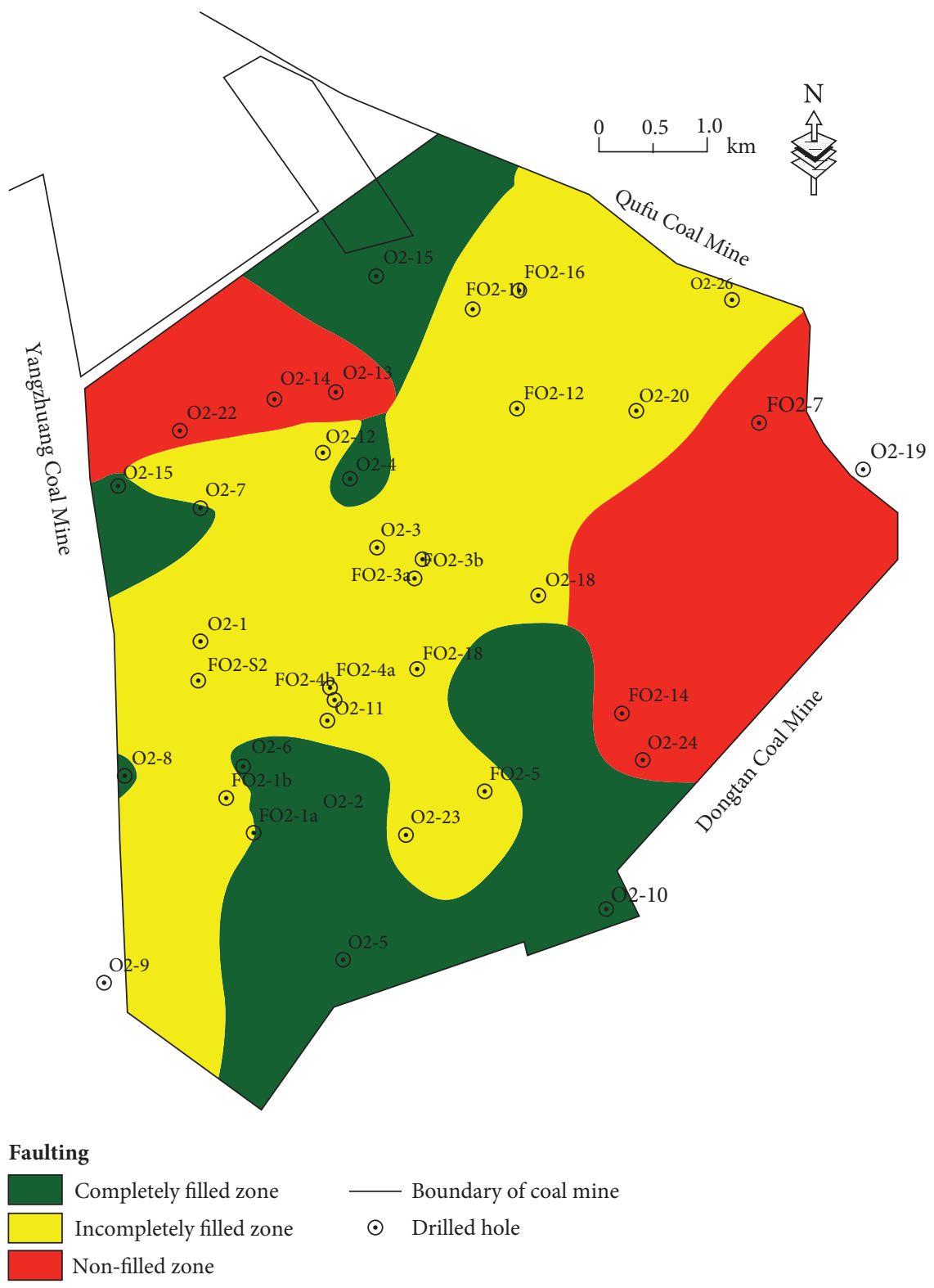

FIGURE 8: The water-resisting property classification of the filling zone on the top of Ordovician limestone.

TABLE 3: The clustering results of WFCM.

\begin{tabular}{|c|c|c|c|c|c|c|}
\hline \multirow[b]{2}{*}{ Clustering categories } & \multicolumn{5}{|c|}{ Clustering center value } & \multirow[b]{2}{*}{ Area $\left(\mathrm{km}^{2}\right)$} \\
\hline & $\begin{array}{l}\text { Interbedded mudstone } \\
\text { thickness ratio }\end{array}$ & $\begin{array}{c}\text { Relative argillaceous } \\
\text { content }\end{array}$ & $\begin{array}{l}\text { Impermeable filling } \\
\text { zone thickness }\end{array}$ & RQD & Faulting & \\
\hline Class 1 & 0.318 & 0.296 & 0.318 & 0.616 & 0.012 & 19.9 \\
\hline Class 2 & 0.132 & 0.201 & 0.313 & 0.640 & 0.015 & 10.1 \\
\hline Class 3 & 0.087 & 0.564 & 0.115 & 0.493 & 0.019 & 12.4 \\
\hline
\end{tabular}

zone, and RQD value of class 3 were all lower than those of the other cluster classes, so class 3 was regarded as the nofill zone. In the study area, the completely filled zone, accounting for $46.9 \%$ of the total area, is mainly distributed in the south and north; the incompletely filled zone (class 2 cluster), accounting for $23.9 \%$, is mainly distributed in the center of the region; and the nonfilled zone (class 3 cluster), accounting for $29.2 \%$, is mainly distributed in the east and northwest.

As indicated by the analysis on field exploration boreholes FO2-14, FO2-S2, and FO2-6, borehole FO2-14 did not contain mudstone in the Ordovician limestone, and, 
when the Ordovician limestone was eventually found, water inflow started and was relatively high, suggesting that this borehole is located within a typical nonfilled zone (class 3 cluster); borehole FO2-S2 showed aluminous mudstone within the limestone, and, when eventually penetrated at $1.44 \mathrm{~m}$, water inflow started and manifested as low water inflow in the early stage and gradual increased with depth, suggesting that this position fell within a typical incompletely filling zone (class 2 cluster); borehole FO2-1a contained purple-red and greyish-green mudstone within the limestone, and no water rush-out was observed before the borehole penetrated the Ordovician limestone at a depth of $11.42 \mathrm{~m}$; after that, there was little water inflow, which gradually increased with time, suggesting that this position fell within a typical completely filled zone (class 1 cluster), which agrees with the evaluation results in Figure 8.

\section{Conclusion}

(1) The formation of the filling zone on the top of Ordovician limestone was accompanied by the development of early Paleozoic karst during the period from the middle Ordovician to the deposition of the Benxi Formation of the middle Carboniferous; after that, it experienced tectonic movement, which created a heterogeneous filling zone with water-resisting properties found throughout the region today

(2) According to field geological investigations on Ordovician outcrop sections, the degrees of development and contact forms of fissure structure planes, and the degrees of filling by argillaceous minerals, three filling zones were identified: completely filled structure, incompletely filled structure, and nonfilled structure

(3) Using the interbedded mudstone thickness ratio, relative argillaceous content, impermeable filling zone thickness, RQD, and faulting as evaluation factors, this paper evaluated the water-resisting properties of the filling zone in the study area based on WFCM and divided it into three zones. On the top of Ordovician limestone in the study area, the completely filled zone has the widest distribution (roughly accounting for $46.9 \%$ of the total area), followed in succession by the nonfilled zone (accounting for 29.2\%) and incompletely filled zone (accounting for 23.9\%). As indicated by field investigations on boreholes, the actual situations revealed by boreholes agreed with the evaluation results

\section{Data Availability}

The data used to support the findings of this study are available from the corresponding author upon request.

\section{Conflicts of Interest}

The authors declare that they have no conflicts of interest.

\section{Acknowledgments}

The authors would like to express their gratitude to everyone who provided assistance for the present study. The study is jointly supported by the "Fundamental Research Funds for the Central Universities" (grant number 2018QNA43).

\section{References}

[1] W. Qiao, W. Li, T. Li, J. Chang, and Q. Wang, "Effects of coal mining on shallow water resources in semiarid regions: a case study in the Shennan mining area, Shaanxi, China," Mine Water and the Environment, vol. 36, no. 1, pp. 104-113, 2017.

[2] L. Yuan, N. Zhang, J. Kan, and Y. Wang, "The concept, model and reserve forecast of green coal resources in China," Journal of China University of Mining \& Technology, vol. 47, no. 1, pp. 1-8, 2018.

[3] J. Wang, H. Kang, J. Liu et al., "Layout strategic research of green coal resource development in China," Journal of China University of Mining \& Technology, vol. 47, no. 1, pp. 15-20, 2018.

[4] W. Qiao, W. Li, and X. Zhang, "Characteristic of water chemistry and hydrodynamics of deep karst and its influence on deep coal mining," Arabian Journal of Geosciences, vol. 7, no. 4, pp. 1261-1275, 2014.

[5] J. Sun, Y. Hu, and G. Zhao, "Relationship between water inrush from coal seam floors and main roof weighting," International Journal of Mining Science and Technology, vol. 27, no. 5 , pp. 873-881, 2017.

[6] H. Yin, J. Wei, L. Lefticariu et al., "Numerical simulation of water flow from the coal seam floor in a deep longwall mine in China," Mine Water and the Environment, vol. 35, no. 2, pp. 243-252, 2016.

[7] Y. Zhou, "Analysis and prevention countermeasures on main water disasters of mine in Shenhua Group," Shenhua Science and Technology, vol. 15, no. 1, pp. 3-7, 2017.

[8] P. W. Huntoon, "Variability of karstic permeability between unconfined and confined aquifers, Grand Canyon region, Arizona," Environmental \& Engineering Geoscience, vol. 6, no. 2, pp. 155-170, 2000.

[9] M. Özler, "Karst hydrogeology of Kusluk-Dilmetas karst springs, Van-Eastern Turkey," Environmental Geology, vol. 41, no. 3-4, pp. 257-268, 2001.

[10] Q. Wu, W. Zhou, G. Pan, and S. Ye, "Application of a discrete-continuum model to karst aquifers in North China," Groundwater, vol. 47, no. 3, pp. 453-461, 2009.

[11] S. Hilberg, V. Arminger, F. Riepler, G. Gschwandtner, and R. Galler, "Hydrogeologie im gipskarst als basis geotechnischer langzeitprognosen im bergbau," Grundwasser, vol. 19, no. 1, pp. 39-49, 2014.

[12] H. R. Nassery, F. Alijani, and M. Nakhaei, "The comparison of hydrodynamic characteristics of karst aquifers: application on two karst formations in Zagros (Asmari and Ilam-Sarvak), southwest Iran," Arabian Journal of Geosciences, vol. 7, no. 11, pp. 4809-4818, 2014.

[13] F. Baechler and R. Boehner, "Karst geology and hydrogeology of Cape Breton Island, Nova Scotia: an overview," Canadian Journal of Earth Sciences, vol. 51, no. 7, pp. 701-714, 2014.

[14] K. E. Eang, T. Igarashi, M. Kondo, T. Nakatani, C. B. Tabelin, and R. Fujinaga, "Groundwater monitoring of an open-pit limestone quarry: water-rock interaction and mixing 
estimation within the rock layers by geochemical and statistical analyses," International Journal of Mining Science and Technology, vol. 28, no. 6, pp. 849-857, 2018.

[15] W. Sun, Q. Wu, H. Liu, and J. Jiao, "Prediction and assessment of the disturbances of the coal mining in Kailuan to karst groundwater system," Physics and Chemistry of the Earth, Parts A/B/C, vol. 89-90, pp. 136-144, 2015.

[16] H. Bai, J. Yang, and C. Wang, "Research on limestone aquifuge in top Ordovician and its application in roadway excavated through graben faults," Journal of Mining \& Safety Engineering, vol. 27, no. 3, pp. 322-329, 2010.

[17] X. X. Miao and H. B. Bai, "Water- resisting characteristics and distribution rule of carbonate strata in the top of Ordovician in North China," Journal of China Coal Society, vol. 36, no. 2, pp. 185-193, 2011.

[18] Q. Wu, X. Jia, D. Cao, and Y. Liang, "Impermeability evaluation method and its application on the ancient weathering crust of carbonatite in middle Ordovician systerm in north China coalfield," Journal of China Coal Society, vol. 29, no. 8, pp. 1735-1741, 2014.

[19] D. Li, W. Yang, C. Wang, Z. Go, Z. He, and B. Sun, "Karstrocks features, types and periods of paleokarst Ordovician in the north of Anhui, China," Journal of Huainan Institute of Technology, vol. 19, no. 1, pp. 5-11, 1999.

[20] Y. Hu and H. Bai, "Erosion mechanism of carbonate in Xinhe Coal Mine," Jiangsu Coal, vol. 2, pp. 10-13, 1995.

[21] L. Di, C. Yang, Y. Yang, X. Ji, and H. Bao, "Solution spot genetic mechanism of Majiagou formation in Ordovician of Ordos Basin," Acta Sedimentologica Sinica, vol. 21, no. 2, pp. 261-262, 2003.

[22] Q. Xuepu, "The formation of gypsum karst collapse-collum and its hydrogeological significance," Carsologica Sinica, vol. 7, no. 4, pp. 344-346, 1988.

[23] Y. Lu, F. Zhang, B. Yan, and X. Guo, "Mechanism of karst development in sulphate rocks and its main geoenvironmental impacts," Acta Geosicientia Sinica, vol. 23, no. 1, pp. 1-6, 2002.

[24] C. Fan and X. Li, "Investigation and analysis on water-bearing degree of the middle of Ordovician in Fengfenggu mountain," Beijing Geology, vol. 13, no. 1, pp. 12-15, 2001.

[25] X. X. Liu and K. J. Yu, "Hydrogeological characteristic of Ordovician in the west of Yanzhou," Coal Geology \& Exploration, vol. 30, no. 1, pp. 38-40, 2002.

[26] M. Zhai and M. Santosh, "Metallogeny of the North China Craton: link with secular changes in the evolving Earth," Gondwana Research, vol. 24, no. 1, pp. 275-297, 2013.

[27] B. Yunlai, M. Yuhu, H. Yong, L. Jianbo, and L. Xiaoguang, "Properties of continental margin and its hydrocarbon exploration significance in Cambrian in the southern Ordos Kratogen of North China," Acta Geologica Sinica (English Edition), vol. 87, no. 3, pp. 777-803, 2013.

[28] G. Shi, Study on sequence stratigraphy and palaeokarst characteristics within sequence stratigraphic framework of Ordovician around southern North China, [M.S. thesis], Chengdu University of Technology, 2010.

[29] H. Chai, Study on filling structure and water-blocking property of the top of Ordovician limestone in Yanzhou coalfield, [M.S. thesis], China University of Mining and Technology, 2015.

[30] J. Zhuang, "Water-resisting property of Benxi Formation of carboniferous and hydrogeological significance of the top filling zone of Ordovician," Coal Geology of China, vol. 8, no. 4, pp. 43-45, 1996.

[31] Q. Wang, W. Li, T. Li, X. Li, and S. Liu, "Goaf water storage and utilization in arid regions of northwest China: a case study of Shennan coal mine district," Journal of Cleaner Production, vol. 202, pp. 33-44, 2018.

[32] D. U. Deere, A. J. Hendron, F. D. Patton, and E. J. Cording, "Design of surface and near-surface construction in rock," in The 8th U.S. Symposium on Rock Mechanics (USRMS), pp. 237-302, Minneapolis, MN, USA, 1966, American Rock Mechanics Association.

[33] W. J. Yu, Q. Gao, X. Q. Jin, and Z. P. Zhang, "Field investigation and mechanics characteristics analysis of deep rock mass affected by fault structure," Progress in Geophysics, vol. 28, no. 1, pp. 488-497, 2013.

[34] Q. Wang, W. Li, W. Chen, and H. Bai, “GIS-based assessment of landslide susceptibility using certainty factor and index of entropy models for the Qianyang County of Baoji city, China," Journal of Earth System Science, vol. 124, no. 7, pp. 1399-1415, 2015.

[35] W. Chen, X. Xie, J. Peng, J. Wang, Z. Duan, and H. Hong, "GIS-based landslide susceptibility modelling: a comparative assessment of kernel logistic regression, Naïve-Bayes tree, and alternating decision tree models," Geomatics, Natural Hazards and Risk, vol. 8, no. 2, pp. 950-973, 2016. 

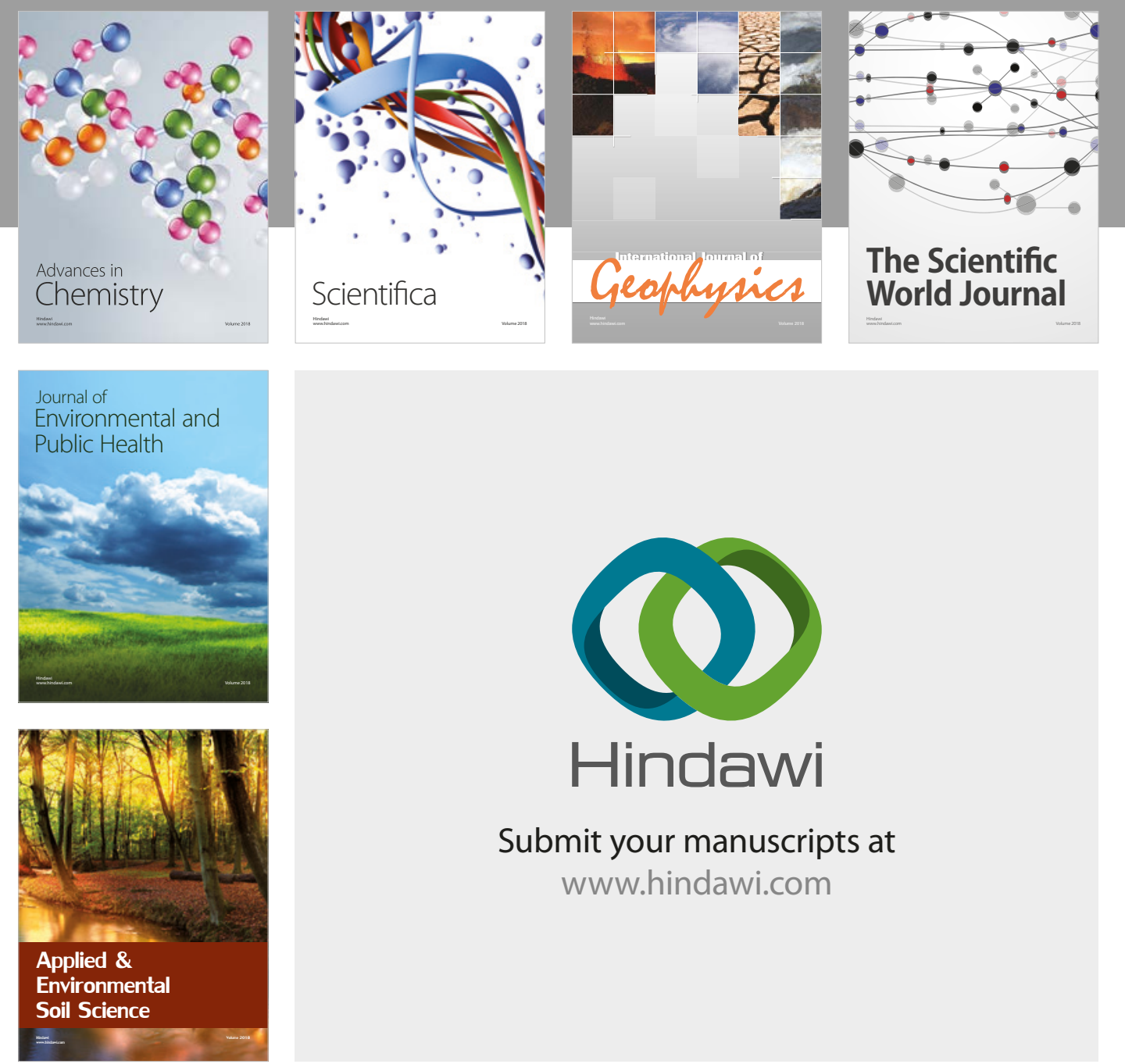

The Scientific

\section{World Journal}
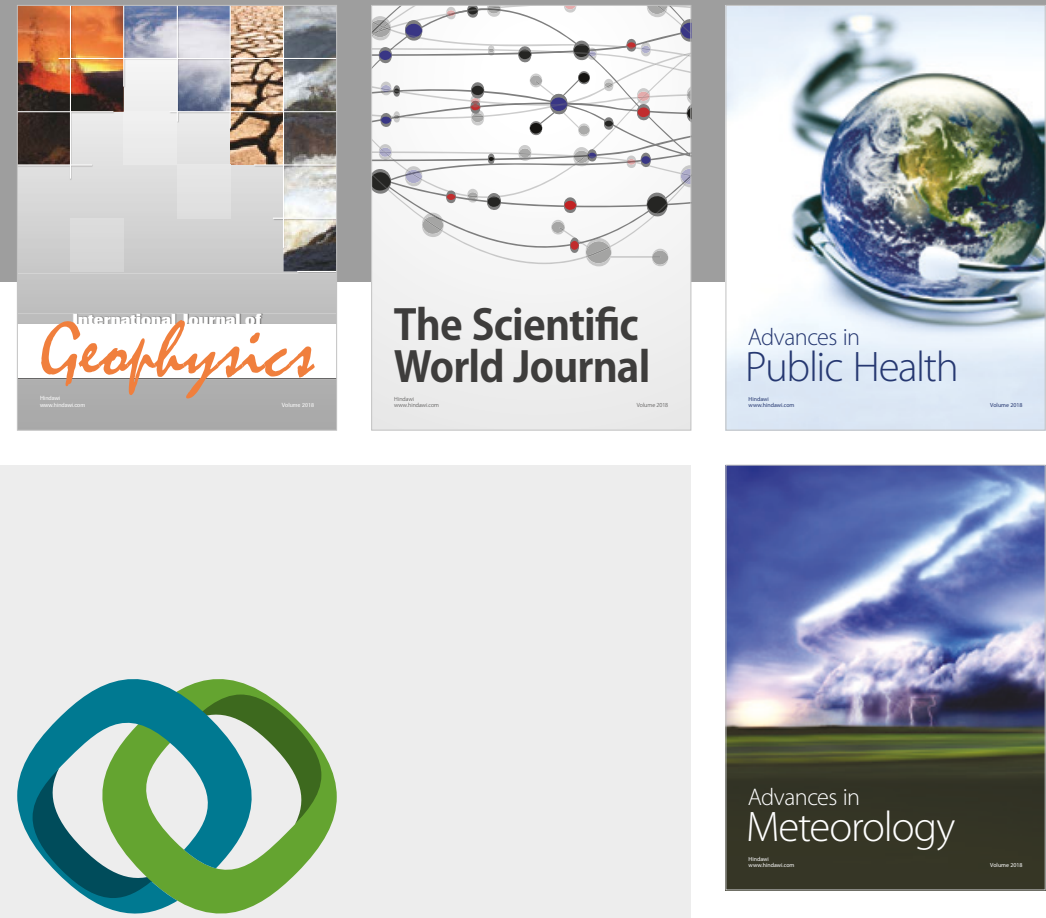

Advan

Public Health

\section{Hindawi}

Submit your manuscripts at

www.hindawi.com
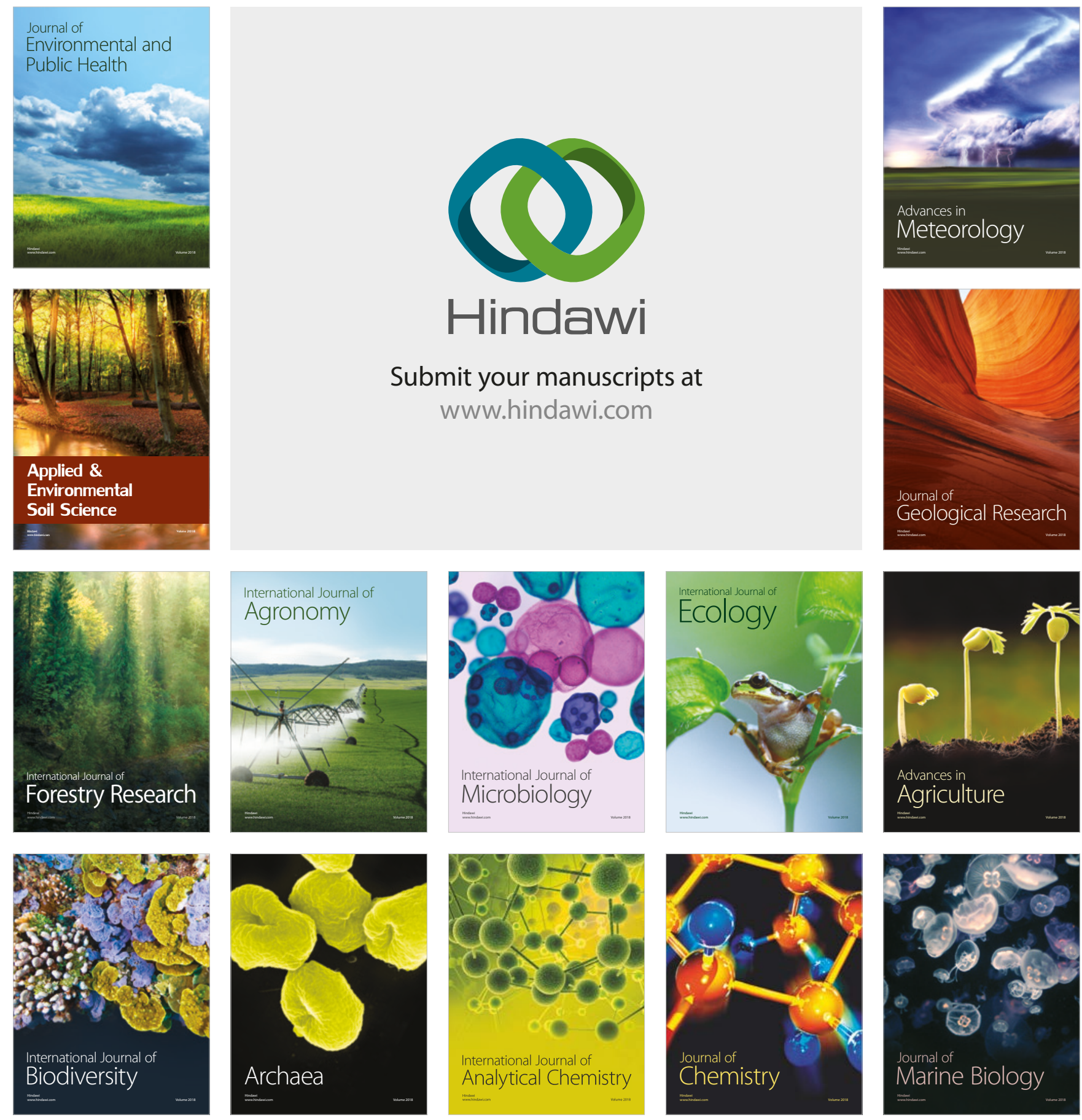